\title{
AKUISISI FONOLOGI ANAK USIA 20 BULAN DALAM KONTEKS PERCAKAPAN SEHARI-HARI : SEBUAH TINJAUAN PSIKOLINGUISTIK
}

\author{
Fitria Aprilia \\ Program Studi Sastra Inggris, Fakultas Keguruan, Ilmu Pendidikan, dan Bahasa \\ Universitas Bina Darma \\ Jalan A. Yani No. 3, Plaju Palembang, Sumatera Selatan, Indonesia \\ fitria_aprilia@binadarma.ac.id
}

\begin{abstract}
ABSTRAK: Penelitian ini bertujuan untuk menggambarkan akuisisi/pemerolehan bahasa pada anak usia 20 bulan (1.8 tahun) ditinjau dari aspek fonologi yang meliputi pemerolehan fonem konsonan, vokal, dan diftong. Studi ini dilakukan di Palembang pada bulan Juli 2021. Metode yang digunakan dalam penelitian ini adalah metode kualitatif melalui pendekatan studi kasus. Data dalam penelitian ini diperoleh dari seorang anak laki-laki dengan inisial MDA sebagai responden. Teknik pengumpulan data dalam studi ini yaitu berupa observasi dan rekam. Berdasarkan hasil analisis diketahui bahwa responden telah mampu menghasilkan beberapa bunyi atau fonem yang ada dalam bahasa Indonesia. Fonem-fonem yang diproduksi terdiri dari fonem konsonan yang sudah muncul sebanyak 9 fonem yaitu /p/, /b/, /t/, /d/, /m/, /n/, /y/, /w/, /y/. Responden juga telah mampu menghasilkan fonem vokal /a/, /i/, /u/, /e/, dan /o/. Bunyi vokal rangkap (diftong) seperti /au/, /ai/, /ue/, dan /ua/ juga telah dikuasai oleh responden.
\end{abstract}

KATA KUNCI: fonem (konsonan, vokal, dan diftong), fonologi, pemerolehan bahasa

\section{PHONOLOGY AQUISITION OF A 20 MONTHS BABY IN DAILY CONVERSATION CONTEXT : A PSYCHOLINGUISTICS STUDY}

\begin{abstract}
The aim of this research is to describe the language acquisition of a child by the age of 20 months / 1.8 years old, seen from the phonological aspects such as phonemes of consonants, vowels, and diphthongs. This research was conducted in Palembang, on July 2021. The method used in this research was qualitative method through case study approach. The data were obtained from a young boy namely MDA as the respondent. The techniques of collecting the data in this research were through observation and recording. The results of the analyses show that the respondent has mastered various phonemes exist in Bahasa Indonesia. These phonemes consist of 9 consonants which are /p/, /b/, /t/, /d/, /m/, /n/, /y/, /w/, /y/. The respondent also has been able to produce the vowel phonemes such as /a/, /i/, /u/, /e/, and /o/. Besides that, it was also found some kinds of diphthongs which are /au /, /ai/, /ue/, and /ua/.
\end{abstract}

KEYWORDS: phonemes (consonants, vocals, diphthongs), phonology, language acquisition

\begin{tabular}{|c|c|c|c|}
\hline $\begin{array}{l}\text { Diterima: } \\
2021-08-12\end{array}$ & Direvisi: & $\begin{array}{l}\text { Distujui: } \\
2021-09-01\end{array}$ & Dipublikasi: \\
\hline \multicolumn{4}{|r|}{$\begin{array}{l}\text { DALAM KONTEKS } \\
\text { GUISTIK. Fon: Jurnal }\end{array}$} \\
\hline
\end{tabular}

\section{PENDAHULUAN}

Kapasitas setiap anak dalam memeroleh atau menyerap suatu bahasa tidaklah sama. Ada anak yang perkembangan bahasanya tergolong cepat, namun ada pula anak yang perkembangan bahasanya tergolong sedang atau bahkan cukup lamban, seperti halnya anak-anak yang belum mampu berbicara dengan jelas walaupun sudah menginjak usia 3 tahun atau lebih.

Perkembangan bahasa anak yang sangat beragam seperti ini menjadi salah satu fenomena yang sangat menarik untuk diteliti. Menurut Sinha, Banerjee, Sinha, \& Shastri, 2009) akuisisi/pemerolehan 
bahasa merupakan salah satu aspek yang paling penting dan menarik dari perkembangan manusia.

Perkembangan akuisisi/pemerolehan bahasa (language acquisition) termasuk ke dalam ranah psikolinguistik, yaitu ilmu bahasa yang objek studinya adalah pengetahuan bahasa, pemakaian bahasa, perubahan bahasa, dan hal-hal lain yang berhubungan dengan aspek-aspek tersebut.

Pengetahuan bahasa berkaitan erat dengan permasalahan kognitif karena unsur bahasa yang diketahui dan dipahami sebenarnya berproses dalam otak. Sedangkan, pemakaian bahasa berkaitan erat dengan praktik pengetahuan bahasa, yaitu pengetahuan manusia yang dikemukakan dalam bentuk pemakaian bahasa.

Sebagai salah satu bidang yang termasuk kedalam domain psikolinguistik, akuisisi/pemerolehan bahasa akhir-akhir ini berkembang dengan pesat. Hal ini disebabkan oleh perubahan pandangan tentang pengajaran dan pembelajaran bahasa, serta semakin gencarnya konsep universal dalam akuisisi/pemerolehan bahasa.

Sebagian ahli psikolinguistik menyatakan bahwa perkembangan bahasa anak terdiri dari beberapa fase tertentu, dimulai dari masa pemerolehan bunyi, membabel, mengucapkan kata, dan lain sebagainya. Namun, pada kenyataannya, tidak semua fase tersebut dilewati oleh setiap anak.

Akuisisi bahasa anak dimulai dengan penyerapan bunyi yang berangsurangsur menjadi beragam suku kata. Dardjowidjojo (2000) berargumen bahwa akuisisi bahasa dapat didefinisikan sebagai suatu penguasaan yang tidak hanya menyangkut kemampuan pelafalan, tetapi juga suatu pengaitan antara bentuk dan makna. Dalam hal ini, ada dua kriteria yang harus dipertimbangkan dalam pemerolehan bahasa. Pertama, anak tersebut telah dapat memproduksi bentuk yang bunyinya dekat dengan bunyi yang dihasilkan orang dewasa. Kedua, anak tersebut sudah dapat mengaitkan bentuk dengan maknanya secara konsisten.

Di sisi lain, muncul suatu perdebatan antara kaum nativis dan empiris. Mukalel (2003) mengatakan bahwa kaum nativis (nature) yang dipelopori oleh Chomsky berpandangan bahwa akuisisi bahasa itu bersifat kodrati dan merupakan suatu proses instingtif yang berlanjut dan berjalan secara konstan dari waktu ke waktu dengan mengikuti jadwal genetik sesuai dengan prinsipel atau parameter yang terdapat pada tata bahasa universal. Di sisi lain, kaum empiris (nurture) yang dipelopori oleh Watson menekankan pada peranan

lingkungan dan tidak mempercayai peran mental dalam pemerolehan pengetahuan.

Dari kedua perbedaan pandangan diatas, maka dapat disimpulkan bahwa pemerolehan bahasa pertama anak dipengaruhi oleh kedua faktor yang telah disebutkan diatas, yakni faktor lingkungan seperti yang dikemukakan oleh kaum empiris (nurture) dan faktor bawaan/ kodrati yang dikemukakan oleh kaum nativis (nature).

Pemerolehan bahasa pertama anak tentu saja dimulai dari unsur bahasa yang paling rendah, yakni fonem atau bunyibunyi huruf. Menurut Brown (2007) sifat dari pemerolehan bahasa pertama adalah spontan, jarang dirancang, dan direncanakan. Pemerolehan ini kemudian dilanjutkan pada tataran yang lebih tinggi, yakni suku kata, kata, kalimat, dan makna. Menurut Mukalel (2003) seorang anak dilahirkan dengan dibekali oleh kemampuan dasar untuk berbahasa dari organ biologis untuk melakukan ujaran, begitu juga dengan kemampuan bawaan untuk memproduksi dan mengkoordinasi ujaran. Fungsi kemampuan biologis dan mental adalah sebagai dasar dalam 
perkembangan bahasa. Tahapan pertama ujaran bayi adalah bunyi babbling yang dicirikan oleh dua sistem bunyi, yaitu bunyi ba....ba, ma.....ma, pa....pa. Tahapan ini disebut juga random articulation atau artikulasi tak beraturan.

Tahap kedua disebut echolia yaitu ujaran yang dihasilkan oleh bayi dengan mengikuti ujaran awal sang ibu dan diakhiri dengan ujaran bayi itu sendiri. Tahap ketiga adalah pengondisian elemenelemen artikulasi oleh objek dan situasi. Tahap ini dicirikan dengan penamaan benda yang ditemukan anak disekitarnya. Tahapan yang terakhir atau keempat yaitu ketika anak sudah mampu menjawab pertanyaan. Anak mulai mampu menggunakan bahasanya secara lebih baik.

Keseluruhan pemerolehan bahasa adalah proses dari sistem internalisasi. Internalisasi linguistik terjadi pada tahapan yang berbeda-beda. Sistem pertama yang diinternalisasi oleh anak adalah sistem bunyi dasar bahasa, yaitu sistem fonologi. Pada tahap ini dari semua materi-materi bahasa yang didengar oleh anak hanyalah serangkaian bunyi yang diinternalisasinya. Keseluruhan proses pemerolehan bahasa adalah salah satu dari sistem internalisasi yakni fonologi, morfologi (kosakata), sintaksis, dan sistem semantik dari bahasa. Mukalel (2003) menyatakan bahwa yang pertama dan menjadi dasar sistem linguistik yang diinternalisasi oleh anak adalah fonologi bahasa.

Akuisisi fonologi anak dimulai dari vokalisasi ke ocehan, kemudian ocehan ke ujaran. Bayi membuat bunyi yang berbeda-beda, misalnya tangisan, tawa, dan sebagainya. Bayi dimanapun, sepertinya, memiliki variasi bunyi yang sama, begitu juga dengan bayi yang terlahir sebagai tuna rungu. Pada usia sekitar 7 bulan, anak-anak biasanya memulai untuk mengoceh, memproduksi hal yang disebut dengan repeated syllables atau pengulangan suku kata. Jenis suku kata dasar yang diulang adalah konsonan ditambah vokal seperti 'baba' dan 'mimi' (Steinberg, Nagata, Aline, 2001). Pemerolehan fonologi anak akan berlanjut pada pemerolehan kata. Setelah diperoleh ujaran, anak menghasilkan ujaran satu kata lalu dua dan tiga kata, setelah itu anak sudah mampu untuk mengelaborasi kata. Anak mulai dapat menambahkan fungsi kata dan perubahan pada ujaran mereka.

Fonologi sendiri adalah salah satu bidang ilmu bahasa yang membahas tentang bunyi-bunyi suatu bahasa tertentu menurut fungsinya untuk membedakan makna leksikal dalam bahasa tersebut. Alduais (2015) mengemukakan bahwa fonologi berhubungan dengan sistem dan pola suara yang ada dengan bahasa tertentu. Sebuah fokus bagi studi fonologi dan juga leksikal adalah tentang cara menetapkan kata-kata anak sehingga menjadi bahasa yang spesifik (Johnson \& Wilson, 2002). Menurut Ladd (2011) ranah bunyi dan ujaran bahasa tergolong kedalam kajian fonologi dan ponetik.

Selanjutnya, dalam bunyi yang diamati adalah bunyi yang dapat membedakan arti yang dikenal dengan fonem. Seperti yang diketahu bahwa fonem adalah satuan bunyi terkecil yang mampu menunjukkan perbedaan makna. Sebagai contoh, misalnya dalam bahasa Indonesia, /k/ dan /l/ merupakan fonem yang berbeda karena /paku/ dengan /palu/ memiliki makna yang tentunya jauh berbeda.

Pemerolehan fonologi merupakan domain penelitian yang penting karena mampu menentukan atau mempengaruhi teori-teori linguistik. Kajian-kajian fonologi yang membahas kerumitan, keteraturan, dan keterbatasan sistem bunyi umumnya dapat menjadi penyokong dan penentu teori-teori linguistik yang dihasilkan oleh pakarnya. 
Ranah fonologi ini juga menarik untuk dikaji dalam pemerolehan bahasa anak-anak karena pemunculan bunyi ini bersifat genetik. Dengan kata lain, munculnya suatu bunyi tidak dapat diukur dengan jumlah tahun atau bulan di kalender karena perkembangan biologis manusia tidaklah sama. Dengan demikian, pemerolehan bahasa setiap anak pasti memiliki variasi.

Berkaitan dengan fenomena ini, ada begitu banyak penelitan-penelitian terdahulu yang telah mengkaji tentang beragam aspek pemerolehan bahasa pada anak. Penelitian-penelitian terdahulu ini dinilai cukup relevan dengan studi yang juga dilakukan oleh peneliti dalam penelitian kali ini.

Penelitian relevan yang pertama yakni studi dari Pierce, Genesee dan Paradis (2012) yang dipublikasikan pada International Journal of Child Language. Penelitian tersebut berjudul acquisition of English grammatical morphology by internationally adopted children from China. Tujuan penelitiannya yaitu untuk mengetahui akuisisi morfologi gramatikal bahasa Inggris anak yang diadopsi dari luar negeri. Hasil studi tersebut menunjukkan bahwa morfem gramatikal yang diperoleh anak tersebut serupa dengan pembelajar bahasa pertama.

Penelitian relevan kedua yakni studi dari Amaro dan Wrembel (2016) yang dipublikasikan dalam International Journal of Multilingualism. Penelitian tersebut berjudul investigating the acquisition of phonology in a third language - a state of the science and an outlook for the future. Studi tersebut berusaha menginvestigasi pemerolehan bahasa ketiga pada anak khususnya pada aspek fonologi.

Selanjutnya, penelitian relevan ketiga ditulis oleh Broselow dan $\mathrm{Xu}$ (2004) dalam International Journal of English Studies. Studi tersebut berjudul differential difficulty in the acquisition of second language phonology. Tujuan studi tersebut yakni melaporkan tentang pemerolehan bahasa Mandarin dari bahasa Inggris yang disuarakan (voiced) dan tidak bersuara (voiceless). Hasilnya, pola bahasa Mandarin pelajar dapat dimengerti dengan menggunakan referen.

Kemudian penelitian relevan yang keempat adalah milik Sams (2015) yang berjudul $\mathrm{T} / N$ pronouns in $L 2$ acquisition of Spanish. Penelitian tersebut dipublikasikan dalam International Journal of Language and Linguistics. Tujuan studi tersebut yaitu menunjukkan bahwa walaupun aturan umum yang mengatur penggunaan T/V di L2 Spanyol sudah cukup, paparan bahasa alami, kesadaran eksplisit akan fenomena mengajar, dan belajar di luar negeri semuanya dapat meningkatkan penguasaan siswa terhadap fenomena pragmatis tersebut.

Penelitian relevan kelima adalah studi milik Sypianska (2016) yang diterbitkan dalam International Journal of Multilingualism yang berjudul Multilingual acquisition of vowels in L1 Polish, L2 Danish and L3 English. Tujuan studi tersebut adalah untuk menentukan apakah semua bahasa dalam repertoar linguistik pembicara multibahasa menunjukkan pengaruh lintas bahasa dan menetapkan arahan pengaruh lintas bahasa berdasarkan vokal terpilih dari repertoar linguistik dua kelompok: kelompok Bilingual (L1 Polish/ L2 Danish) dan kelompok Multilingual (L1 Polish / L2 Danish / L3 English). Hasilnya menunjukkan bahwa huruf vokal L1 Polandia lebih tinggi dan lebih tipis akibat pengaruh bahasa Inggris L2 Danish dan L3.

Berbeda dengan penelitianpenelitian relevan di atas, studi ini berusaha untuk mengungkapkan beragam bunyi yang dihasilkan oleh seorang anak berusia 20 bulan (1.8 tahun) dan permasalahan fonologi yang muncul 
dalam memproduksi bahasa dalam bentuk kata. Penelitian ini bertujuan untuk menggambarkan fonem-fonem (konsonan, vokal, dan diftong) yang diproduksi oleh anak usia 20 bulan (1.8 tahun).

Penelitian ini diharapkan dapat memberikan pengetahuan pada masyarakat pada umumnya terutama kalangan pendidik dan para ibu yang memiliki balita mengenai perkembangan akuisisi/pemerolehan bahasa anak.

\section{METODE}

Penelitian ini merupakan penelitian deskriptif. Data yang diperoleh dari penelitian ini dianalisis dengan metode kualitatif karena bukan merupakan data numerik. Jadi, penelitian ini secara keseluruhan merupakan studi deskriptif kualitatif. Pendekatan yang digunakan adalah studi kasus. Penelitian ini merupakan sebuah studi kasus terhadap seorang anak laki-laki yang untuk selanjutnya disebut responden. Data berupa bunyi ujaran yang ditranskripsikan dalam bentuk transkripsi fonetis diambil pada bulan Juli 2021. Pada saat pengambilan data, subjek penelitian berusia 20 bulan. Berikut ini adalah data responden:

Inisial : MDA

Lahir : Palembang, 1 Desember 2019

Alamat: Lrg. Musi Indah No. 1925 Pakjo, Palembang

Responden lahir dan menetap di Palembang dengan orang tua dan lingkungan yang menggunakan bahasa Indonesia sebagai bahasa sehari-hari. Oleh sebab itu, bahasa Indonesia merupakan bahasa pertama bagi responden. Bahasa pertama ibu dan ayahnya adalah bahasa Palembang. Orang-orang disekitarnya kerap menggunakan bahasa Indonesia ketika berkomunikasi dengan responden. Teknik pengumpulan data menggunakan tiga tahapan strategis yang berurutan, yakni 1) metode penyediaan data, 2) metode analisis data, dan 3) metode penyajian hasil analisis.

Metode penyediaan data adalah suatu tahapan penelitian yang menggambarkan bagaimana data penelitian diperoleh. Metode analisis data merupakan tahapan puncak dari suatu penelitian. Tahapan ini menentukan ditemukan atau tidaknya kaidah yang menjadi sumber sekaligus sasaran obsesi suatu penelitian.

Selanjutnya, metode penyajian hasil analisis adalah tahapan terakhir yang berusaha mengemukakan hasil tahapan puncak.

Dalam penyediaan data, teknik yang diaplikasikan dalam penelitian ini adalah teknik observasi yang diikuti dengan teknik rekam. Data yang berupa ujaran ditranskripsikan ke dalam transkripsi fonetis. Selanjutnya, transkripsi tersebut dijadikan korpus-korpus yang akan dipisah-pisahkan sesuai dengan kebutuhan. Korpus-korpus tersebut diklasifikasikan ke dalam bentuk fonem dan kata. Selanjutnya, semua korpus yang berbentuk fonem didata dan dikelompokkan menjadi fonem vokal dan fonem konsonan.

\section{HASIL DAN PEMBAHASAN}

\section{Fonologi}

Berdasarkan penelitian yang telah dilakukan, diketahui bahwa MDA selanjutnya disebut responden, telah mampu menghasilkan beberapa bunyi atau fonem yang ada dalam bahasa Indonesia. Jika dibandingkan dengan rekan seusianya, responden termasuk anak yang cukup cepat dan aktif dalam menyerap bunyi serta menggunakan bahasa. Untuk lebih jelasnya, fonem-fonem yang sudah dihasilkan responden dirangkum dalam tabel-tabel berikut:

\section{a. Konsonan}

Fonem konsonan yang sudah muncul sebanyak 9 fonem yaitu $/ \mathrm{p} /, \mathrm{b} /$, $/ \mathrm{t} /, / \mathrm{d} /, / \mathrm{m} /, / \mathrm{n} /, / \mathrm{y} /, / \mathrm{w} /, / \mathrm{y} /$. Bunyi letupan bilabial [p] dan [b] dilafalkan dengan 
jelas, baik yang terdapat di awal, di tengah, maupun di akhir kata seperti pada tabel di bawah ini:

[p] [papi] 'papi' dan [dapat] 'dapat'

[b] [buta] 'buka' dan [biyu] 'biru'

Bunyi letupan lamino-alveolar [t] dan [d] dilafalkan dengan jelas, baik yang terdapat di awal maupun di akhir kata seperti pada tabel di bawah ini:

[t] [tante] 'tante', dan [tutu] 'susu' [tatut] 'takut'

[d] [dede] 'dedek' dan [ade] 'adek'

Bunyi nasal bilabial [m] dan laminoalviolar [n] dapat dilafalkan dengan jelas, baik yang terdapat di awal, di tengah, maupun di akhir kata seperti pada tabel di bawah ini:

[m] [matan] 'makan' dan [mami] 'mami' [yumah] 'rumah'

[n] [bunda] 'bunda' dan [boneta] 'boneka'

Bunyi nasal dorso-velar [y] pada suku kata akhir diucapkan dengan jelas seperti pada tabel di bawah ini:

[y] [tunin] 'kuning'

[bintan] 'bintang'

Bunyi hampiran bilabial [w] dan lamino palatal [y] dilafalkan dengan jelas, baik yang terdapat di awal, di tengah, maupun di akhir kata seperti pada tabel di bawah ini:

[w] [wayna] 'warna' dan [awan] 'awan'

[y] [ayam] 'ayam' dan [ayo] 'ayo'

Bunyi getar [r] belum muncul. Sehingga bunyi tersebut dilafalkan dengan bunyi sampingan seperti:

[b] [biyu] 'biru' dan [yumah] 'rumah'

Di usia 20 bulan ini, tampaknya ada konsonan yang sudah dikuasai responden dengan baik, dan dapat dilafalkan dengan jelas. Ada pula konsonan yang telah dikuasai namun masih berfluktuasi dengan bunyi lain dan bahkan ada bunyi yang sama sekali belum dikuasainya. Meskipun demikian, dalam mengucapkan fonem tertentu, hasil observasi memperlihatkan bahwa responden terkadang juga melakukan pola substitusi.

\section{b. Vokal dan Diftong}

Bunyi-bunyi vokal yang muncul berdasarkan hasil pengamatan terhadap responden adalah sebagai berikut.

Bunyi vokal [a] merupakan bunyi huruf pertama yang dikuasai responden secara utuh. Bunyi tersebut muncul dan dapat dilafalkan dengan jelas, baik yang muncul di awal, di tengah, atau di akhir kata. Bunyi vokal [a] di awal, tengah, dan akhir kata muncul seperti pada kata berikut:

Awal [a] [ada] 'ada' dan [ayam] 'ayam'

Tengah [a] [mami] 'mami'

[tata] 'kakak'

Akhir [a] [apa] 'apa'

Bunyi vokal [i] muncul dan dilafalkan dengan jelas, baik yang ada di awal, di tengah, atau di akhir kata. Bunyi vokal [i] di awal, tengah, dan akhir kata muncul seperti pada kata berikut:

Awal [i] [ikut] 'itut' dan [ikan] 'itan'

Tengah [i] [tiup] 'tiup'

[cium] 'tium'
Akhir
[i] [papi] 'papi'
[mami] 'mami'

Bunyi vokal $[\mathrm{u}]$ muncul dan dilafalkan dengan jelas, baik yang terletak pada awal, tengah, atau akhir kata. Bunyi vokal [u] di awal, tengah, dan akhir kata muncul seperti pada kata berikut:

Awal [u] [umur] 'umuy'

Tengah [u] [butan] 'bukan'

Akhir [u] [itu] 'itu'

Bunyi vokal [e] muncul dan dilafalkan dengan jelas, baik yang terletak pada awal, tengah, atau akhir kata. Bunyi vokal [e] di awal, tengah, dan akhir kata muncul seperti pada kata berikut: 
Awal [e] [enam] 'enam'

Tengah [e] [ade] 'adek'

[boneta] 'boneka'

Akhir [e] [ume] 'ume'

Bunyi vokal [o] muncul dan dilafalkan dengan jelas, baik yang ada di awal, di tengah, atau di akhir kata. Bunyi vokal [o] di awal, tengah, dan akhir kata muncul seperti pada kata berikut:

Awal [o] [oyay] 'orang' dan [om] 'oom'

Tengah [o] [bobo] 'bobok'

Akhir [o] [tado] 'kado'

Selanjutnya, bunyi vokal rangkap yang muncul adalah [au], [ai], [ue] dan [ua]. Bunyi tersebut muncul pada kata berikut: [au] [tau] 'tau' dan [mau] 'mau'

[ai] [nai] 'naik'

[ue] [tue] 'kue'

[ua] [uay] 'uang'

Bunyi diftong yang muncul dilafalkan dengan vokal adalah [au] dan [ai]. Bunyi diftong [au] dan [ai] muncul seperti kata berikut:

[au] [pito] 'pisau' dan

[ai] [pate] 'pakai'

Berdasarkan penjelasan di atas, dapat diketahui bahwa responden telah menguasai fonem vokal bahasa Indonesia. Vokal-vokal tersebut mampu dilafalkan dengan baik terletak pada awal, tengah, ataupun akhir kata.

\section{KESIMPULAN}

Kesimpulan hanya menjawab permasalahan atau tujuan penelitian. Penulis bisa menambahkan teori/konsep baru dari hasil temuan dalam penelitian. Penulis boleh menambahkan impikasi dan saran namun tidak diperbolehkan menggunakan bullet, list atau numbering.

\section{DAFTAR PUSTAKA}

Alduais. A.M.S. (2015). An account of phonetics and phonology as similar identical or different. The
International Journal of Indian Psychology, 3(1), 157-165.

Amaro, J. C., \& Wrembel, M. (2016). Investigating the acquisition of phonology in a third language - a state of the science and an outlook for the future. International Journal of Multilingualism, 13(4), 395-409.

Broselow, E., \& Xu, Z. (2004). Differential difficulty in the acquisition of second language phonology. International Journal Of English Studies, 4(2), 135-163.

Brown, D. (2007). Principles of learning and teaching. New Jersey: Prentice Hand Reagent.

Dardjowidjojo, S. (2000). Echa: Kisah Pemerolehan Bahasa Anak Indonesia. Jakarta: Grasindo.

Johson, C. E., \& Wilson, I. L. (2002). Phonetic evidence for early language differentiation: Research issues and some preliminary data. The International Journal of Bilingualism, 6(3), 271-289.

Ladd, D. R. (2011). Phonetics in Phonology. Wiley-Blackwell, Chichester.

Mukalel, J. C. (2003). Psychology of Language Learning. New Delhi: Discovery Publishing House.

Pierce, L. J., Genesee, F., \& Paradis, J. (2012). Acquisition of English grammatical morphology by internationally adopted children from China. International Journal of Child Language, 1(1), 1-15.

Sams, C. D. (2015). T/V pronouns in L2 acquisition of Spanish. International Journal of Language and Linguistics, 3(3), 182-186

Sinha, A., Banerjee, N., Sinha, A., \& Shastri, R. K. (2009). Interference of first language in the acquisition of second language. Journal of Psychology and Counseling, 1(7), 117-122. 
Prom Studi Pendidikan Bahasa dan Sastra Indonesia

FKIP Universitas Kuningan

Steinberg, D. D., Nagata, H., \& Aline, D.P. (2001). Psycholinguistics Language, Mind and World. New York: Longman
Sypianska, J. (2016). Multilingual acquisition of vowels in L1 Polish, L2 Danish and L3 English. International Journal of Multilingualism, 13(4), 476-495. 